\title{
水分亏缺下化肥减量配施有机肥对棉花光合特性与产量的影响
}

\author{
冯克云 ${ }^{1}$ 王 宁 $^{1, *}$ 南宏宇 ${ }^{1}$ 高建刚 $^{2}$
}

${ }^{1}$ 甘肃省农业科学院作物研究所, 甘肃兰州 $730070{ }^{2}$ 北京市农林科学院, 北京 100097

摘 要: 于 2017 年和 2018 年进行田间定位试验, 采用裂区试验设计, 主区为充分灌溉 $\mathrm{W}_{1}$ (灌水量 $4800 \mathrm{~m}^{3} \mathrm{hm}^{-2}$ ) 和 亏缺灌溉 $\mathrm{W}_{2}$ (灌水量 $2400 \mathrm{~m}^{3} \mathrm{hm}^{-2}$ ), 副区为不施肥 $(\mathrm{CK})$ 、单施化肥 $(\mathrm{CF}) 、 75 \%$ 化肥 $+25 \%$ 有机肥 $\left(\mathrm{M}_{1}\right) 、 50 \%$ 化肥 $+50 \%$ 有机肥 $\left(\mathrm{M}_{2}\right) 、 25 \%$ 化肥 $+75 \%$ 有机肥 $\left(\mathrm{M}_{3}\right) 5$ 个处理, 研究了化肥减量配施有机肥对棉花光合特性及产量的影响, 以期为 水分亏缺下合理利用有机肥、减少化肥投入提供理论依据。结果表明, 亏缺灌溉下棉花叶面积指数(leaf area index, $\mathrm{LAI}) 、$ 净光合速率 $\left(P_{\mathrm{n}}\right)$ 、气孔导度 $\left(G_{\mathrm{s}}\right)$ 、地上部干物质积累量和籽棉产量均低于充分灌溉, 但灌溉水生产力 (irrigation water productivity, IWP)和胞间 $\mathrm{CO}_{2}$ 浓度 $\left(C_{\mathrm{i}}\right)$ 高于充分灌溉。化肥减量配施有机肥较单施化肥能显著提高盛蕾期后棉 花 LAI, 提高棉花各生育期 $P_{\mathrm{n}}$ 和 $G_{\mathrm{s}}$, 增加棉花营养器官和生殖器官干物质积累量, 并促进干物质向生殖器官转运, 提高籽棉产量和 IWP, 能在盛铃期和吐絮期提高土壤耕层含水量。充分灌溉下, 各有机肥配施处理间棉花 LAI、 $P_{\mathrm{n}}$ 和籽棉产量均表现为 $\mathrm{M}_{1}>\mathrm{M}_{2}>\mathrm{M}_{3}$, 其中 $\mathrm{M}_{1}$ 籽棉产量 2 年平均分别较 $\mathrm{CF} 、 \mathrm{CK}$ 提高了 $6.9 \%$ 和 $62.1 \%$; 亏缺灌溉下, 各 有机肥配施处理间棉花 LAI、 $P_{\mathrm{n}}$ 和籽棉产量表现为 $\mathrm{M}_{2}>\mathrm{M}_{1}>\mathrm{M}_{3}$, 其中 $\mathrm{M}_{2}$ 籽棉产量 2 年平均分别较 $\mathrm{CF} 、 \mathrm{CK}$ 提高了 $19.9 \%$ 和 $79.3 \%$ 。化肥减量配施有机肥在水分亏缺下有利于籽棉增产, 缓解水分亏缺对棉花生长发育的影响, 其中 $\mathrm{M}_{2}$ $(50 \%$ 化肥 $+50 \%$ 有机肥) 为最佳施肥处理。

关键词：棉花; 水分亏缺; 有机肥; 光合特性; 产量

\section{Effects of chemical fertilizer reduction with organic fertilizer application under water deficit on photosynthetic characteristics and yield of cotton}

\author{
FENG Ke-Yun ${ }^{1}$, WANG Ning ${ }^{1, *}$, NAN Hong-Yu ${ }^{1}$, and GAO Jian-Gang ${ }^{2}$ \\ ${ }^{1}$ Institute of Crop Sciences, Gansu Academy of Agricultural Sciences, Lanzhou 730070, Gansu, China; ${ }^{2}$ Beijing Academy of Agriculture and \\ Forestry Sciences, Beijing 100097, China
}

\begin{abstract}
Fixed position experiments were conducted in 2017 and 2018, and split plot arrangement with the main treatment for full irrigation $\left(\mathrm{W}_{1}\right)$ with irrigation amount was 4800 cubic meters per hectare and deficit irrigation $\left(\mathrm{W}_{2}\right)$ was 2400 cubic meters per hectare, and the secondary treatment including treatments without fertilization (CK), single application of chemical fertilizer (CF), $75 \%$ chemical fertilizer with $25 \%$ organic fertilizer $\left(\mathrm{M}_{1}\right)$, $50 \%$ chemical fertilizer with $50 \%$ organic fertilizer $\left(\mathrm{M}_{2}\right)$, and $25 \%$ chemical fertilizer with $75 \%$ organic fertilizer $\left(\mathrm{M}_{3}\right)$. The effects of chemical fertilizer reduction and organic fertilizer application on photosynthetic characteristics and yield of cotton were studied to provide theoretical basis for rational utilization of organic fertilizer and reduction of chemical fertilizer input under water deficit. Under deficit irrigation, leaf area index (LAI), net photosynthetic rate $\left(P_{\mathrm{n}}\right)$, stomatal conductance $\left(G_{\mathrm{s}}\right)$, above-ground dry matter accumulation and seed yield of cotton were all lower than that under full irrigation, while irrigation water productivity (IWP) and intercellular $\mathrm{CO}_{2}$ concentration $\left(C_{\mathrm{i}}\right)$ were higher. The chemical fertilizer reduction combined with application of organic fertilizer could effectively improve the LAI after the full squaring stage, improve $P_{\mathrm{n}}$ and $G_{\mathrm{s}}$ of cotton in all stage, promote the accumulation of vegetative and reproductive organs dry mat-
\end{abstract}

本研究由甘肃省科技重大专项(17ZD2NA016-6), 国家重点研发计划项目(2017YFD0201905)和甘肃省农业科学院中青年基金项目 (2019GAAS38)资助。

This study was supported by the Major Science and Technology Project of Gansu Province (17ZD2NA016-6), the National Key Research and Development Program of China (2017YFD0201905), and the Youth Foundation Project of Gansu Academy of Agricultural Sciences (2019GAAS38).

“通信作者(Corresponding author): 王宁, E-mail: wangn2828@163.com

第一作者联系方式: E-mail: fengkymh@163.com

Received (收稿日期): 2020-03-26; Accepted (接受日期): 2020-08-19; Published online (网络出版日期): 2020-09-15.

URL: https://kns.cnki.net/kcms/detail/11.1809.S.20200914.1742.004.html 
ter, improve its transfer to the reproductive organs, improve the IWP and seed yield, and also increase the moisture content of soil surface in the period of full boll stage and boll opening stage. The effects among different organic fertilizer treatments on LAI, $P_{\mathrm{n}}$ and seed yield were all presented as $\mathrm{M}_{1}>\mathrm{M}_{2}>\mathrm{M}_{3}$, and under the treatment of $\mathrm{M}_{1}$, the average seed cotton yield of two years increased compared with $\mathrm{CF}$ and $\mathrm{CK}$ by $6.9 \%$ and $62.1 \%$ respectively. Whereas, the effects under deficit irrigation were presented as $M_{2}>M_{1}>M_{3}$, and the two years' average seed yield increased by $19.9 \%$ and $79.3 \%$ respectively compared with $C F$ and CK under $\mathrm{M}_{2}$. Chemical fertilizer reduction and organic fertilizer application were beneficial to increase the yield of seed cotton under water deficit, and alleviate the influence of water deficit on cotton growth and development, $\mathrm{M}_{2}(50 \%$ fertilizer $+50 \%$ organic fertilizer) was the best treatment.

Keywords: cotton; water deficit; organic fertilizer; photosynthetic characteristics; yield

光合作用是作物产量形成的基础 ${ }^{[1]}$, 受水肥、光 照、温度、大气 $\mathrm{CO}_{2}$ 浓度等多种因子的影响, 其中水 肥调控是最有效的管理措施 ${ }^{[2]}$ 。水分不足是干旱区 农业生产中限制作物生长发育最主要的逆境因子 ${ }^{[3]}$, 轻度的干旱胁迫能够降低叶片净光合速率、气孔导 度和胞间 $\mathrm{CO}_{2}$ 浓度, 随着干旱程度的加剧会破坏光 化学活性和光合电子需求间的平衡, 损伤光合机构, 最终影响光合产物的积累和产量的形成 ${ }^{[4-6]}$ 。在干旱 缺水地区, 施肥在“以肥调水”中起着十分重要的作 用 ${ }^{[7]}$, 在水分亏缺下适量增施氮肥, 可以提高作物 叶片的光合性能, 促进植株生长发育并有效提高作 物产量和水分利用效率, 减小干旱对作物造成的不 利影响 ${ }^{[8-9]}$, 但在长期大量单施化肥导致土壤质量下 降并出现环境问题的地区, 并不利于农业的可持续 发展。有机肥富含大量有益菌和作物所需微量元素, 能够均衡土壤养分, 改善土壤结构 ${ }^{[10]}$, 释放土壤固 定态元素, 提高土壤通透性和保水性, 增加作物产 量和提高水分利用率 ${ }^{[7,11]}$, 有机肥与化肥配施能够 结合化肥速效性和有机肥持久性的特点, 在提高作 物产量和土壤培肥上具有重要意义 ${ }^{[12]}$, 是解决化肥 施用不合理问题的有效途径之一 ${ }^{[13]}$, 但由于有机肥 中养分的矿化分解受水分影响较大, 在不同的土壤 水分条件下有机肥配施化肥结果会有差异 ${ }^{[14]}$ 。因此, 需要明确在特定水分条件下有机肥配施化肥对作物 生长发育的调控效应。

甘肃河西走廊棉区是西北内陆棉区的重要组成 部分, 是我国优质棉花生产区 ${ }^{[15]}$, 但该地区水资源 圆乏, 农业用水矛盾突出, 水分亏缺已成为影响当 地棉花产业发展最为严重的逆境因子 ${ }^{[16]}$, 同时随着 水肥一体化施肥模式的发展以及为了获取更高的产 量效益, 棉田单位面积化肥施用量不断增加而缺乏 有机质的投入, 盲目施肥现象比较普遍 ${ }^{[17]}$, 造成土 壤肥力下降、养分失衡和环境污染等一系列问题, 因此, 需要在有限水分条件下调整和优化施肥结构, 协同减小水分亏缺的危害并降低单施化肥的负面效
应。以往研究主要关注于化肥氮对水分亏缺的补偿 效应 ${ }^{[1,8,18]}$ 和有机肥与氮肥配施对棉花的调控效 应 ${ }^{[19]}$, 而未见在水分亏缺下化肥减量配施有机肥对 棉花光合特性及产量形成方面研究的报道。为此, 本文拟通过研究水分亏缺下化肥减量配施有机肥对 棉花光合特性及产量的影响, 明确棉花在水分亏缺 下对有机肥不同配施比例的生物学响应, 以期通过 适宜的有机肥配施化肥改善棉花光合特性, 缓解水 分胁迫的影响, 为合理利用水肥资源、减少化肥投 入提供理论依据。

\section{1 材料与方法}

\section{1 试验区概况}

甘肃省农业科学院敦煌棉花试验站位于甘肃省 敦煌市魏家桥村, 东经 $94^{\circ} 38^{\prime}$, 北纬 $40^{\circ} 17^{\prime}$, 该地区 海拔 $1138 \mathrm{~m}$, 年平均气温 $10.5^{\circ} \mathrm{C}$, 年均降雨量约 39.9 $\mathrm{mm}$, 蒸发量 $2486 \mathrm{~mm}$, 无霜期 $145 \mathrm{~d}$, 是典型的大陆 干旱性气候。试验地土壤为灌淤土, 最大田间持水量 $19.3 \%$ 、饱和持水量 $31.4 \%$, 在播种前 $14 \mathrm{~d}$ 浇足水, 平 整土地, 各处肥力均匀, 在播前采集土壤样品测定理 化性质。2017 年和 2018 年土壤理化性质见表 1, 棉 花生育期内降雨量和平均气温见图 1 。

\section{2 试验设计}

试验采用裂区设计, 主区为灌水量, 分别为充 分灌溉 $\left(\mathrm{W}_{1}\right.$ ), 灌溉量为 $4800 \mathrm{~m}^{3} \mathrm{hm}^{-2}$ (当地棉田常规 灌溉量)和亏缺灌溉 $\left(\mathrm{W}_{2}\right)$, 灌溉量为 $2400 \mathrm{~m}^{3} \mathrm{hm}^{-2}$ (充分灌溉量的 $50 \%$ ), 灌溉量用灌水管末端的水表 控制计量, 全生育期灌溉 4 次, 于棉花现蕾后(2017 年 6 月 15 日, 2018 年 6 月 20 日)开始每隔 $20 \mathrm{~d}$ 灌水 1 次, 其中 $\mathrm{W}_{2}$ 每次灌溉量为 $\mathrm{W}_{1}$ 的 $50 \%$; 副区为 5 个不同的施肥处理, 分别为不施肥 $(\mathrm{CK})$ 、单施化肥 (CF)、75\%化肥 $+25 \%$ 有机肥 $\left(\mathrm{M}_{1}\right) 、 50 \%$ 化肥 $+50 \%$ 有 机肥 $\left(\mathrm{M}_{2}\right) 、 25 \%$ 化肥 $+75 \%$ 有机肥 $\left(\mathrm{M}_{3}\right)$, 配施比例是 根据氮肥用量计算, 棉花全生育期各处理的氮磷钾 肥施用量保持相同, 均为 $\mathrm{N} 450 \mathrm{~kg} \mathrm{hm}^{-2} 、 \mathrm{P}_{2} \mathrm{O}_{5} 90 \mathrm{~kg}$ 
$\mathrm{hm}^{-2} 、 \mathrm{~K}_{2} \mathrm{O} 40 \mathrm{~kg} \mathrm{hm}^{-2}$, 磷和钾不足的用化肥补足。 试验所用有机肥含有机质 $45.0 \%$ 、全氮 $7.2 \%$ 、 全磷 2.6\%、全钾 $2.2 \%$, 在棉花播种前作基肥一次性 施入，供试化肥为尿素 $(\mathrm{N} 46 \%)$ 、过磷酸钙 $\left(\mathrm{P}_{2} \mathrm{O}_{5}\right.$ $11 \%)$ 、硫酸钾 $\left(\mathrm{K}_{2} \mathrm{O} 50 \%\right)$, 各处理磷、钾、 $20 \%$ 化肥 氮做底肥，于播种前一次性深施，剩余 $80 \%$ 化肥氮
根据棉花生长需肥特性按 $25 \% 、 25 \% 、 25 \% 、 25 \%$ 比 例分 4 次随灌溉水施入。试验棉花品种为陇棉 3 号, 地膜覆盖种植, 1 膜 4 行, 株距 $15 \mathrm{~cm}$, 行距 $40 \mathrm{~cm}$, 种植密度为 16.5 万株 $\mathrm{hm}^{-2}$, 小区面积 $38.4 \mathrm{~m}^{2}$ $(8.0 \mathrm{~m} \times 4.8 \mathrm{~m})$, 重复 3 次, 各小区间距 $2 \mathrm{~m}$, 并用 $80 \mathrm{~cm}$ 地膜垂直埋设隔离水肥渗透。
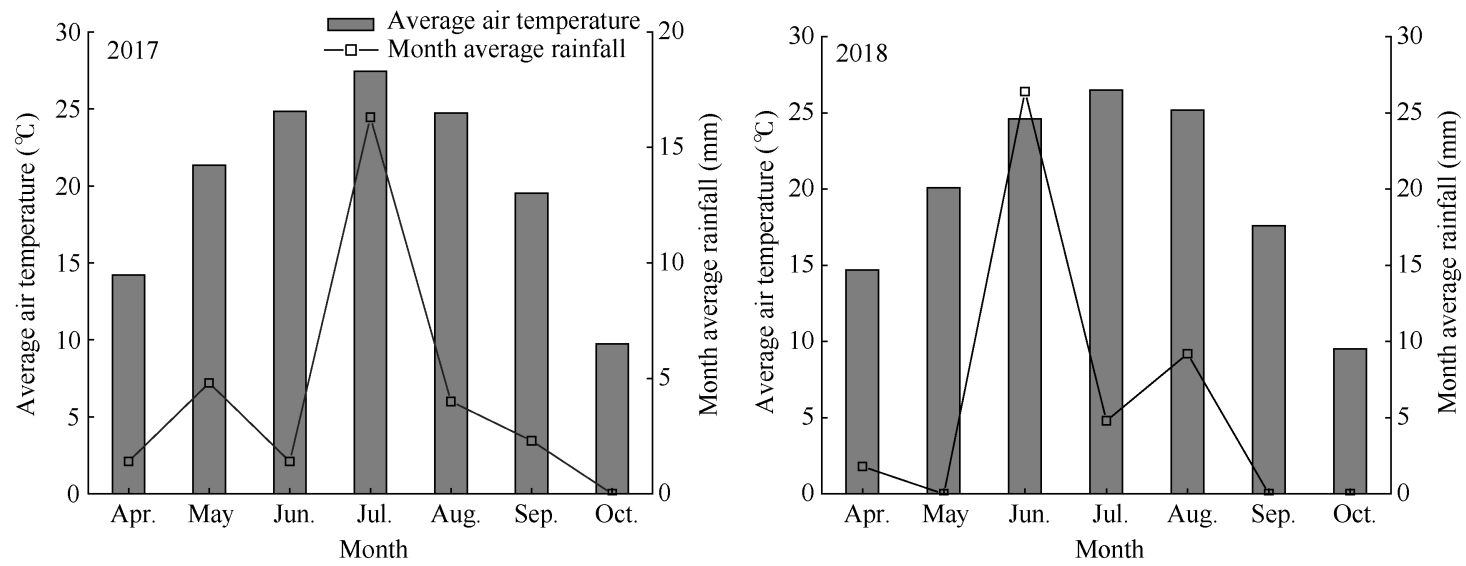

图 12017 年和 2018 年棉花生育期内月平均气温和降雨量

Fig. 1 Month average air temperature and rainfall in growth period of cotton in 2017 and 2018

表 1 试验田 $0 \sim 60 \mathrm{~cm}$ 土层土壤养分含量

Table 1 Nutrients content in $0-60 \mathrm{~cm}$ soil layer of the experimental field before sowing

\begin{tabular}{|c|c|c|c|c|c|c|c|}
\hline $\begin{array}{l}\text { 年份 } \\
\text { Year }\end{array}$ & $\begin{array}{c}\text { 土层 } \\
\text { Soil layer } \\
(\mathrm{cm})\end{array}$ & $\mathrm{pH}$ & $\begin{array}{c}\text { 有机质 } \\
\text { Organic matter } \\
\left(\mathrm{g} \mathrm{kg}^{-1}\right)\end{array}$ & $\begin{array}{c}\text { 全氮 } \\
\text { Total nitrogen } \\
\left(\mathrm{g} \mathrm{kg}^{-1}\right)\end{array}$ & $\begin{array}{c}\text { 碱解氮 } \\
\text { Alkaline-hydrolytic N } \\
\left(\mathrm{mg} \mathrm{kg}^{-1}\right)\end{array}$ & $\begin{array}{c}\text { 速效磷 } \\
\text { Available P } \\
\left(\mathrm{mg} \mathrm{kg}^{-1}\right)\end{array}$ & $\begin{array}{c}\text { 速效钾 } \\
\text { Available K } \\
\left(\mathrm{mg} \mathrm{kg}^{-1}\right)\end{array}$ \\
\hline \multirow[t]{3}{*}{2017} & $0-20$ & 7.26 & 12.81 & 0.62 & 59.62 & 28.35 & 191.27 \\
\hline & $20-40$ & 7.31 & 9.78 & 0.51 & 46.84 & 21.38 & 125.34 \\
\hline & $40-60$ & 7.38 & 6.54 & 0.45 & 36.97 & 15.63 & 82.61 \\
\hline \multirow[t]{3}{*}{2018} & $0-20$ & 7.14 & 13.46 & 0.67 & 57.35 & 29.46 & 187.35 \\
\hline & $20-40$ & 7.25 & 10.15 & 0.54 & 48.82 & 24.37 & 122.82 \\
\hline & $40-60$ & 7.32 & 7.52 & 0.42 & 39.67 & 17.62 & 87.65 \\
\hline
\end{tabular}

\section{3 测定项目与方法}

\subsection{1 叶面积指数(LAI)}

2017 年和 2018 年于棉 花盛蕾期、盛花期、盛铃前期、盛铃期、盛铃后期、 吐絮期, 相应为播种后 48、76、93、108、121 和 $132 \mathrm{~d}$, 采用 LAI-2000 冠层仪(LI-Cor, USA)测定棉花叶面积 指数, 具体测定方法参照王谦等 ${ }^{[20]}$, 每个小区重复 测定 5 次。

1.3.2 光合参数 2017 年和 2018 年于棉花盛蕾 期、盛花期、盛铃期、吐絮期，用便携式光合仪 Li-6400 (Li-COR, USA)测定主茎功能叶片净光合速 率 $\left(P_{\mathrm{n}}\right)$ 、气孔导度 $\left(G_{\mathrm{s}}\right)$ 、胞间 $\mathrm{CO}_{2}$ 浓度 $\left(C_{\mathrm{i}}\right)$ 等光合生 理指标, 打顶前选取主茎功能叶倒四叶, 打顶后选
取主茎倒三叶。测定时间为晴朗无云天气的上午 9:00-11:30，每处理测定 5 片叶，取平均值。

1.3.3 地上部千物质积累与分配于棉花盛蕾 期、盛花期、盛铃期和吐絮期，在每小区选取代表 性植株 5 株, 按营养器官(茎、叶)和生殖器官(蕾、花、 铃)分开, $105^{\circ} \mathrm{C}$ 杀青 $30 \mathrm{~min}$, 之后在 $80^{\circ} \mathrm{C}$ 恒温烘干至 恒重, 称量其地上部干物质量并计算营养器官与生 殖器官的分配量。

1.3.4 产量与产量结构 2017年和2018年在棉花 吐絮期记录各小区株数和朎数; 吐絮后对各小区收 获籽棉, 晒干后称重计产; 每次收棉花时取 100 铃晾 干后称重计算单铃重, 重复3次。 
1.3.5 土壤含水量 2018年在棉花盛蕾期、盛花 期、盛铃期和吐絮期，采用 5 点取样法采集 $0 \sim 20 \mathrm{~cm}$ 土壤, 采用烘干法测定土壤含水量, 每个处理3次重 复。

1.3.6 计算公式 灌溉水生产力IWP $\left(\mathrm{kg} \mathrm{m}^{-3}\right)=$ 籽棉产量 $(\mathrm{kg})$ /总灌溉量 $\left(\mathrm{m}^{3}\right)$, 土壤含水量 $(\%)=$ (湿 土重-烘干土重) /烘干土重 $\times 100 \%$ 。

\section{4 统计分析}

采用 Microsoft Excel 2007 录入和整理试验数据, 采用 Origin Pro 2018 作图, 采用 DPS 7.5 软件统计分 析数据, 采用 Duncan's 法多重比较 $(P<0.05)$ 。

\section{2 结果与分析}

\section{1 不同灌溉量下化肥减量配施有机肥对棉花} 叶面积指数的影响

不同灌溉量下各施肥处理棉花叶面积指数(LAI) 在 2017 年和 2018 年随生育进程的变化趋势相同 (图 2), 从盛蕾期到吐絮期均呈先升后降的趋势, 但
不同灌溉量下 LAI 达到峰值的时期不同，其中充分 灌溉 $\mathrm{W}_{1}$ 在盛铃期达到最大, 而亏缺灌溉 $\mathrm{W}_{2}$ 在盛铃 前期达到最大。方差分析表明, $\mathrm{W}_{2}$ 各生育期 LAI 显 著低于 $\mathrm{W}_{1}(P<0.05)$, 在盛蕾期、盛花期、盛铃期和 吐絮期较 $\mathrm{W}_{1} 2$ 年平均分别下降 $22.4 \% 、 15.9 \% 、 17.3 \%$ 和 $14.2 \%$, 表明水分亏缺显著影响棉花植株叶片生 长，不利于光合生产。不同施肥处理间 LAI 在各生 育期存在显著差异，充分灌溉 $\mathrm{W}_{1}$ 下，LAI 在不同有 机肥配施处理间随有机肥配施比例的增加而降低, 表现为 $\mathrm{M}_{1}>\mathrm{M}_{2}>\mathrm{M}_{3}$, 其中 $\mathrm{M}_{1}$ 在各生育期 LAI 均显著 高于其他施肥处理 $(P<0.05)$, 较 $\mathrm{CF}$ 在盛蕾期、盛花 期、盛铃期和吐絮期 2 年平均分别提高 $4.4 \% 、 8.4 \%$ 、 $7.3 \%$ 和 $16.1 \%$; 亏缺灌溉 $\mathrm{W}_{2}$ 下，在盛蕾期 $\mathrm{M}_{1}$ 处理 LAI 最高，从盛花期到吐絮期，各施肥处理间表现 为 $\mathrm{M}_{2}>\mathrm{M}_{1}>\mathrm{M}_{3}>\mathrm{CF}>\mathrm{CK}$, 其中 $\mathrm{M}_{2}$ 较 $\mathrm{CF}$ 在盛花期、 盛铃期和吐絮期 2 年平均分别提高 $11.6 \% 、 10.3 \%$ 和 $20.3 \%, \mathrm{M}_{1}$ 分别提高 $8.3 \% 、 5.5 \%$ 和 $14.9 \%, \mathrm{M}_{3}$ 分别提 高 $6.2 \%$ 、1.7\%和 $13.8 \%$ 。
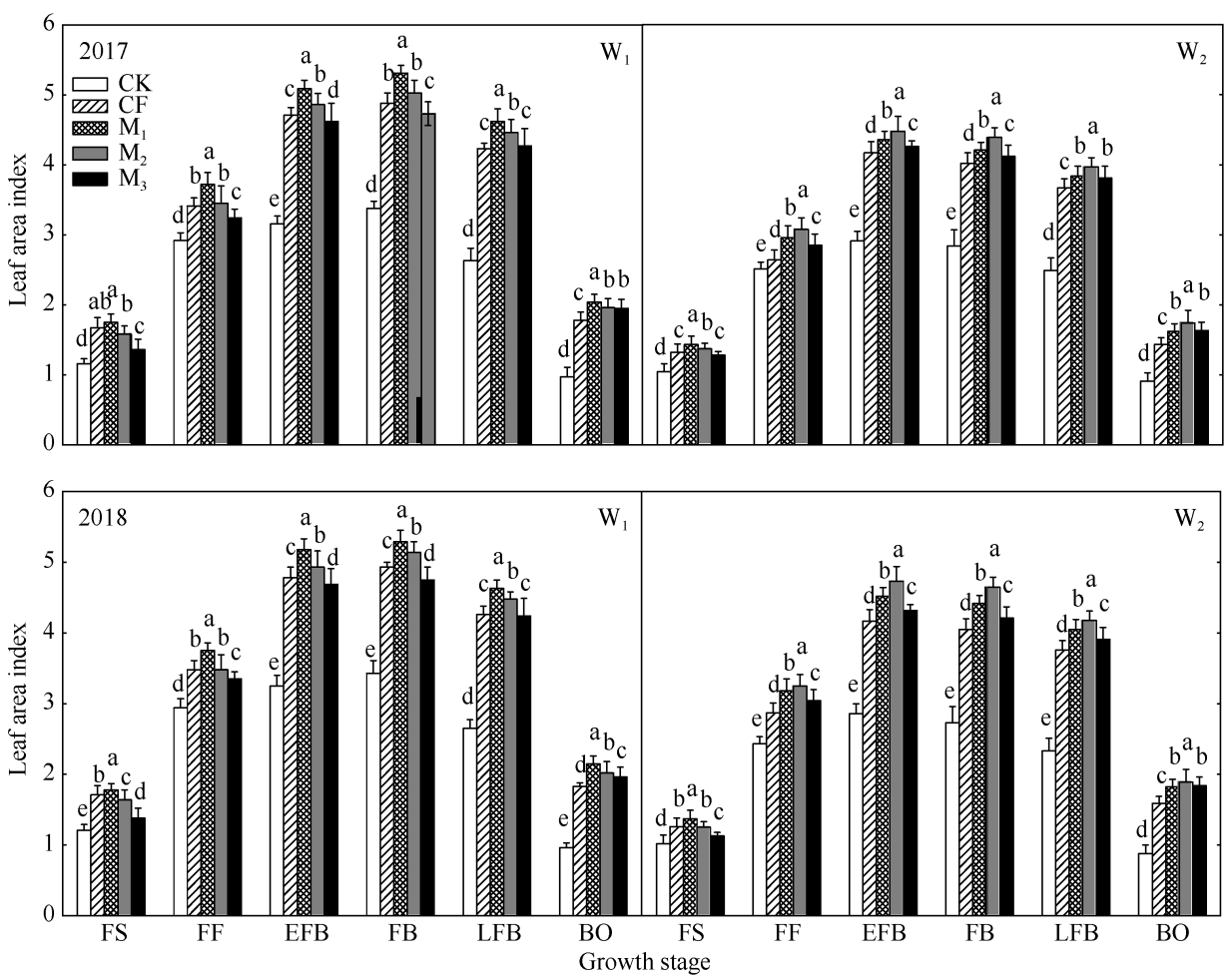

图 2 不同灌溉量和施肥处理对棉花叶面积指数的影响

Fig. 2 Effects of different irrigation and fertilizer treatments on leaf area index of cotton

不同字母表示同一生育期不同施肥处理差异显著 $(P<0.05)$ 。 FS: 盛蕾期; FF：盛花期; EFB：盛铃前期; FB：盛铃期; LFB：盛铃后期; BO: 吐絮期。CK: 不施肥; $\mathrm{CF}$ : 单施化肥; $\mathrm{M}_{1}: 75 \%$ 化肥 $+25 \%$ 有机肥; $\mathrm{M}_{2}: 50 \%$ 化肥 $+50 \%$ 有机肥; $\mathrm{M}_{3}: 25 \%$ 化肥 $+75 \%$ 有机肥。 $\mathrm{W}_{1}$ : 充分 灌溉 $4800 \mathrm{~m}^{3} \mathrm{hm}^{-2} ; \mathrm{W}_{2}$ : 亏缺灌溉 $2400 \mathrm{~m}^{3} \mathrm{hm}^{-2}$ 。

Different letters in the same stage mean significant difference among different fertilizer treatments at $P<0.05$. FS: full squaring stage; FF: full flowering stage; EFB: early stage of full boll; FB: full boll stage; LFB: later full boll stage; BO: boll opening stage. CK: no fertilizer; CF: single application of chemical fertilizer; $\mathrm{M}_{1}: 75 \%$ chemical fertilizer $+25 \%$ organic fertilizer; $\mathrm{M}_{2}: 50 \%$ chemical fertilizer $+50 \%$ organic fertilizer; $\mathrm{M}_{3}: 25 \%$ chemical fertilizer $+75 \%$ organic fertilizer. $\mathrm{W}_{1}$ : full irrigation with irrigation amount was $4800 \mathrm{~m}^{3} \mathrm{hm}^{-2} ; \mathrm{W}_{2}:$ deficit irrigation with irrigation amount was $2400 \mathrm{~m}^{3} \mathrm{hm}^{-2}$. 
2.2 不同灌溉量下化肥减量配施有机肥对棉花 光合特性的影响

由图 3 可知, 棉花净光合速率 $\left(P_{\mathrm{n}}\right)$ 从盛蕾期到吐 絮期 2 年变化趋势一致, 呈先上升后下降的趋势, 在盛花期达到最大值。亏缺灌溉 $\mathrm{W}_{2}$ 较充分灌溉 $\mathrm{W}_{1}$ 棉花 $P_{\mathrm{n}}$ 显著降低 $(P<0.05)$, 在盛蕾期、盛花期、盛铃 期及吐絮期分别平均下降 9.4\%、2.5\%、2.8\%和 $8.3 \%$ 。 充分灌溉 $\mathrm{W}_{1}$ 下, 化肥减量配施有机肥处理间 $P_{\mathrm{n}}$ 随 有机肥配施量的增大而降低, 表现为 $\mathrm{M}_{1}>\mathrm{M}_{2}>\mathrm{M}_{3}$, 其中 $M_{1}$ 在盛蕾期、盛花期、盛铃期及吐絮期较 $C F$ 两年平均分别提高 $1.8 \% 、 2.8 \% 、 3.2 \%$ 和 $10.6 \%, \mathrm{M}_{2}$ 和 $M_{3}$ 在盛蕾期、盛花期、盛铃期与 $C F$ 无显著差异, 但在吐絮期显著高于 $\mathrm{CF}$, 不施肥 $\mathrm{CK}$ 在各生育期 $P_{\mathrm{n}}$ 均显著低于其他施肥处理 $(P<0.05)$ 。亏缺灌溉 $\mathrm{W}_{2}$ 下, 各施肥处理间 $P_{\mathrm{n}}$ 表现为 $\mathrm{M}_{2}>\mathrm{M}_{3}>\mathrm{M}_{1}>\mathrm{CF}>\mathrm{CK}$, 其中 $\mathrm{M}_{2}$ 在各生育期 $P_{\mathrm{n}}$ 最高, 在盛蕾期、盛花期、盛铃期 和吐絮期较 CF 2 年平均分别提高 $4.7 \% 、 7.1 \% 、 2.9 \%$ 和 $7.2 \%$ 。不施肥 $\mathrm{CK}$ 在各生育期均显著低于各施肥 处理 $(P<0.05)$ 。弓缺灌溉 $\mathrm{W}_{2}$ 下棉花气孔导度 $\left(G_{\mathrm{s}}\right)$ 较 充分灌溉 $\mathrm{W}_{1}$ 显著下降 $(P<0.05)$, 在盛蕾期、盛花 期、盛铃期、吐絮期 2 年平均分别降低 $5.6 \% 、 2.3 \%$ 、
$3.1 \%$ 和 $3.1 \%$, 说明水分亏缺不同程度地限制了气孔 开放, 导致光合性能降低。充分灌溉 $\mathrm{W}_{1}$ 下, 有机肥 配施处理间 $G_{\mathrm{s}}$ 表现为 $\mathrm{M}_{1}>\mathrm{M}_{2}>\mathrm{M}_{3}, \mathrm{M}_{1}$ 处理在各生育 期 $G_{\mathrm{s}}$ 最高, 在盛蕾期、盛花期、盛铃期和吐絮期平 均较 CF 分别提高 $8.0 \% 、 6.5 \% 、 11.1 \%$ 和 $8.1 \%$, 不 施肥 $\mathrm{CK}$ 在各生育期均显著低于其他处理。亏缺灌 溉 $\mathrm{W}_{2}$ 下，各施肥处理间 $G_{\mathrm{s}}$ 在各生育期表现为 $\mathrm{M}_{2}>\mathrm{M}_{3}>\mathrm{M}_{1}>\mathrm{CF}>\mathrm{CK}$ (2017 年吐絮期除外), 其中 $\mathrm{M}_{2}$ 提高效应最显著, 较 $\mathrm{CF}$ 在盛蕾期、盛花期、盛铃期 及吐絮期 2 年平均分别提高 $5.8 \% 、 6.7 \% 、 9.4 \%$ 和 $3.9 \%$ 。胞间 $\mathrm{CO}_{2}$ 浓度 $\left(C_{\mathrm{i}}\right)$ 与 $P_{\mathrm{n}}$ 和 $G_{\mathrm{s}}$ 在各生育期变化 呈相反趋势, 从盛蕾期到吐絮期表现为先下降后升 高, 在盛花期达到最小值。亏缺灌溉 $\mathrm{W}_{2}$ 下棉花 $C_{\mathrm{i}}$ 较充分灌溉 $\mathrm{W}_{1}$ 显著增大 $(P<0.05)$, 较 $\mathrm{W}_{1}$ 在棉花盛 蕾期、盛花期、盛铃期及吐絮期 2 年平均分别提高 $5.6 \% 、 4.1 \% 、 3.4 \%$ 和 $6.4 \%$ 。充分灌溉 $\mathrm{W}_{1}$ 下，各施 肥处理间 $C_{\mathrm{i}}$ 表现为 $\mathrm{M}_{1}<\mathrm{M}_{2}<\mathrm{M}_{3}<\mathrm{CF}<\mathrm{CK}, \mathrm{M}_{1}$ 较 $\mathrm{CF}$ 在 盛蕾期、盛花期、盛铃期分别降低 $5.2 \% 、 8.1 \% 、 6.4 \%$ 和 $4.2 \%$; 亏缺灌溉 $\mathrm{W}_{2}$ 下, 施肥处理间 $C_{\mathrm{i}}$ 表现为 $\mathrm{M}_{2}<\mathrm{M}_{3}<\mathrm{M}_{1}<\mathrm{CF}<\mathrm{CK}$, 其中 $\mathrm{M}_{2}$ 较 $\mathrm{CF}$ 在盛蕾期、盛花 期、盛铃期分别降低 $7.2 \% 、 14.6 \% 、 8.3 \%$ 和 $6.4 \%$ 。

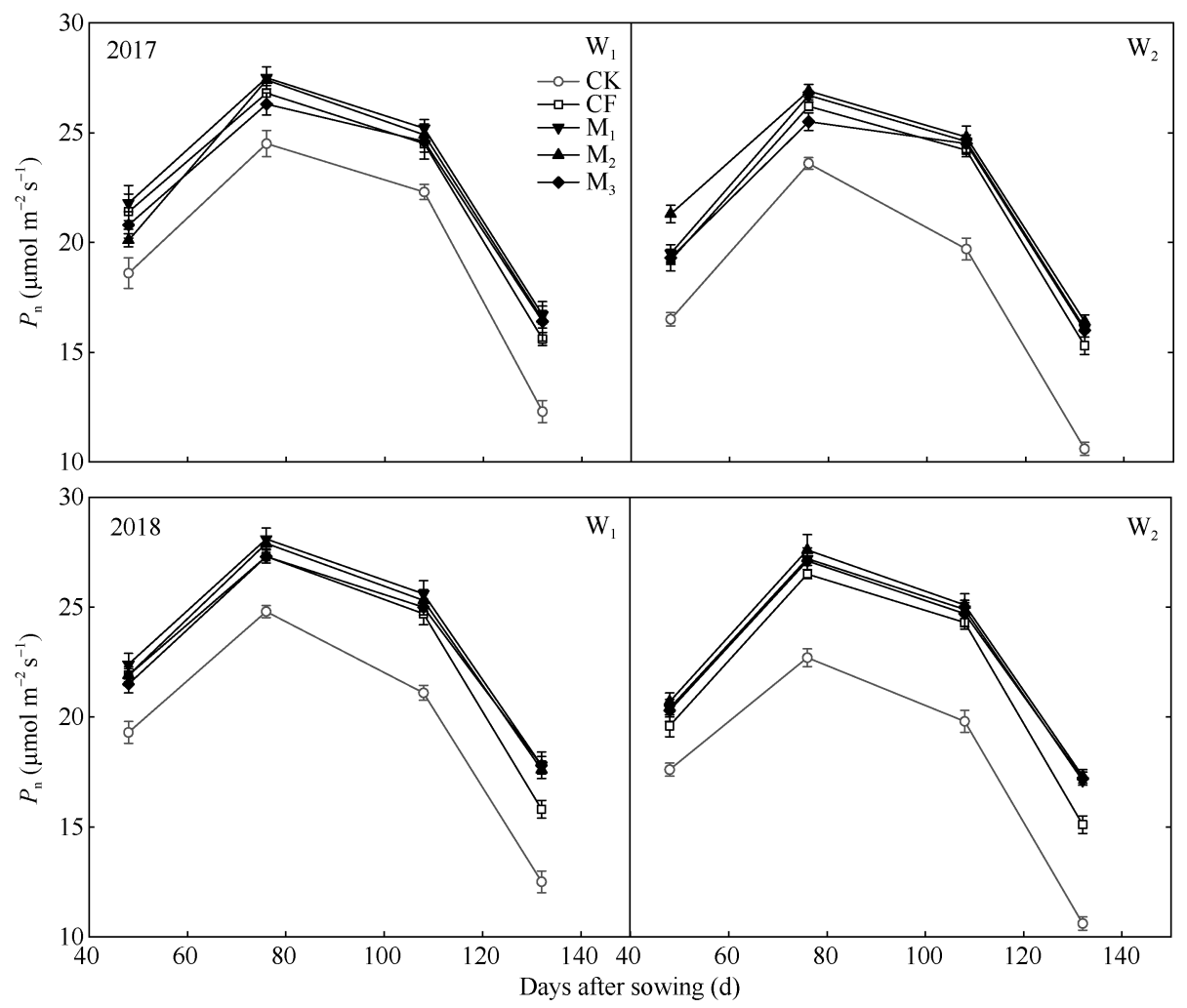



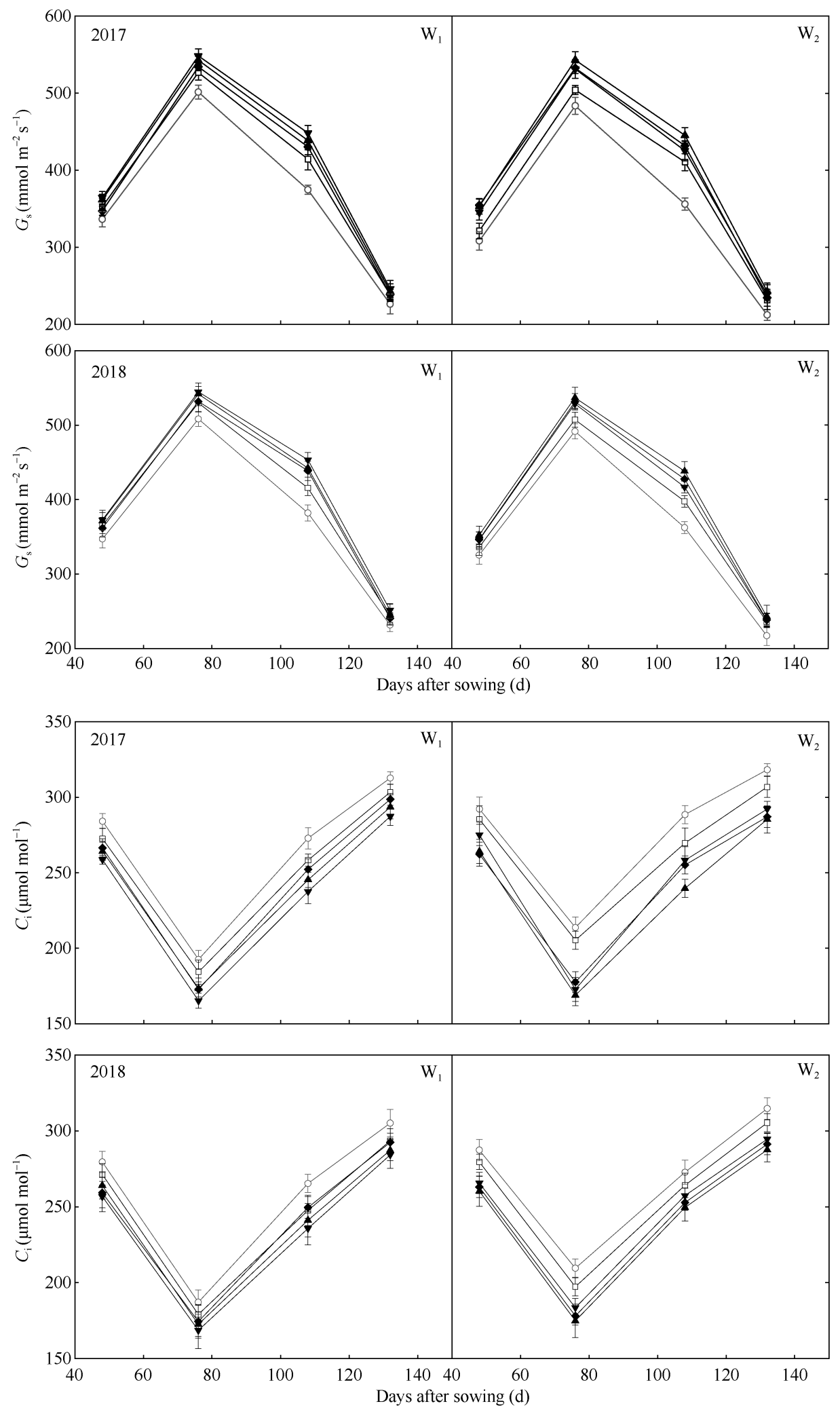

图 3 不同灌溉量和施肥处理对棉花光合特性的影响

Fig. 3 Effects of different irrigation and fertilizer treatments on leaf photosynthetic characteristics of cotton 处理同图 2。Treatments are the same as those given in Fig. 2. 
2.3 不同灌溉量下化肥减量配施有机肥对棉花 地上部干物质积累量及分配的影响

由图 4 可知, 充分灌溉与亏缺灌溉下各施肥处 理营养器官和生殖器官干物质积累量均随生育进程 的推进而逐渐增加, 2 年趋势一致。亏缺灌溉 $\mathrm{W}_{2}$ 较 充分灌溉 $\mathrm{W}_{1}$ 各施肥处理营养器官和生殖器官积累 量降低而干物质向生殖器官分配比例提高, 在盛蕾 期、盛花期、盛铃期和吐絮期营养器官干物质积累 量 2 年平均分别降低 $13.8 \% 、 11.3 \% 、 10.2 \%$ 和 $14.0 \%$, 生殖器官分别降低 $4.4 \% 、 4.9 \% 、 4.3 \% 、 3.2 \%$ ，地上 部干物质向生殖器官分配比例提高 $5.1 \%$, 表明在水 分亏缺条件下, 棉花的营养器官与生殖器官的生长 受到了抑制, 并适当提高了光合产物向生殖器官的 分配比例。充分灌溉 $W_{1}$ 下, 盛蕾期各施肥处理营养 器官和生殖器官干物质积累量无显著差异, 但均显 著高于 $\mathrm{CK}(P<0.05)$, 盛铃期后各施肥处理间差异逐
渐增大, 其中 $\mathrm{M}_{1}$ 在各施肥处理中地上部干物质积累 量以及干物质向棉铃分配比例均为最高, 在盛花 期、盛铃期和吐絮期营养器官干物质积累量较 $\mathrm{CF}$ 分别提高 $6.3 \%$ 、 $13.5 \%$ 、 $6.3 \%$, 生殖器官干物质积 累量分别提高 $13.3 \%$ 、9.8\%、11.2\%, 向生殖器官分 配比例提高 $4.7 \%$ 。亏缺灌溉 $\mathrm{W}_{2}$ 下, 各施肥处理地 上部干物质积累量在盛蕾期无显著差异, 而从盛花 期到吐絮期差异增大，各施肥处理干物质积累量表 现为 $M_{2}>M_{1}>M_{3}>C F>C K$, 其中 $M_{2}$ 较 $C F$ 在盛花期、 盛铃期、吐絮期营养器官干物质积累量 2 年平均分 别提高 $15.9 \%$ 、 $17.3 \%$ 和 $18.2 \%$, 生殖器官干物质积 累量提高 $24.2 \%$ 、32.2\%和 $28.9 \%$, 干物质向生殖器 官分配比例提高 $4.1 \%$, 表明水分亏缺下化肥减量配 施有机肥能显著提高棉花营养器官和生殖器官干物 质积累量, 并促进光合产物向生殖器官的分配, 其 中 $\mathrm{M}_{2}$ 提高效果最显著。
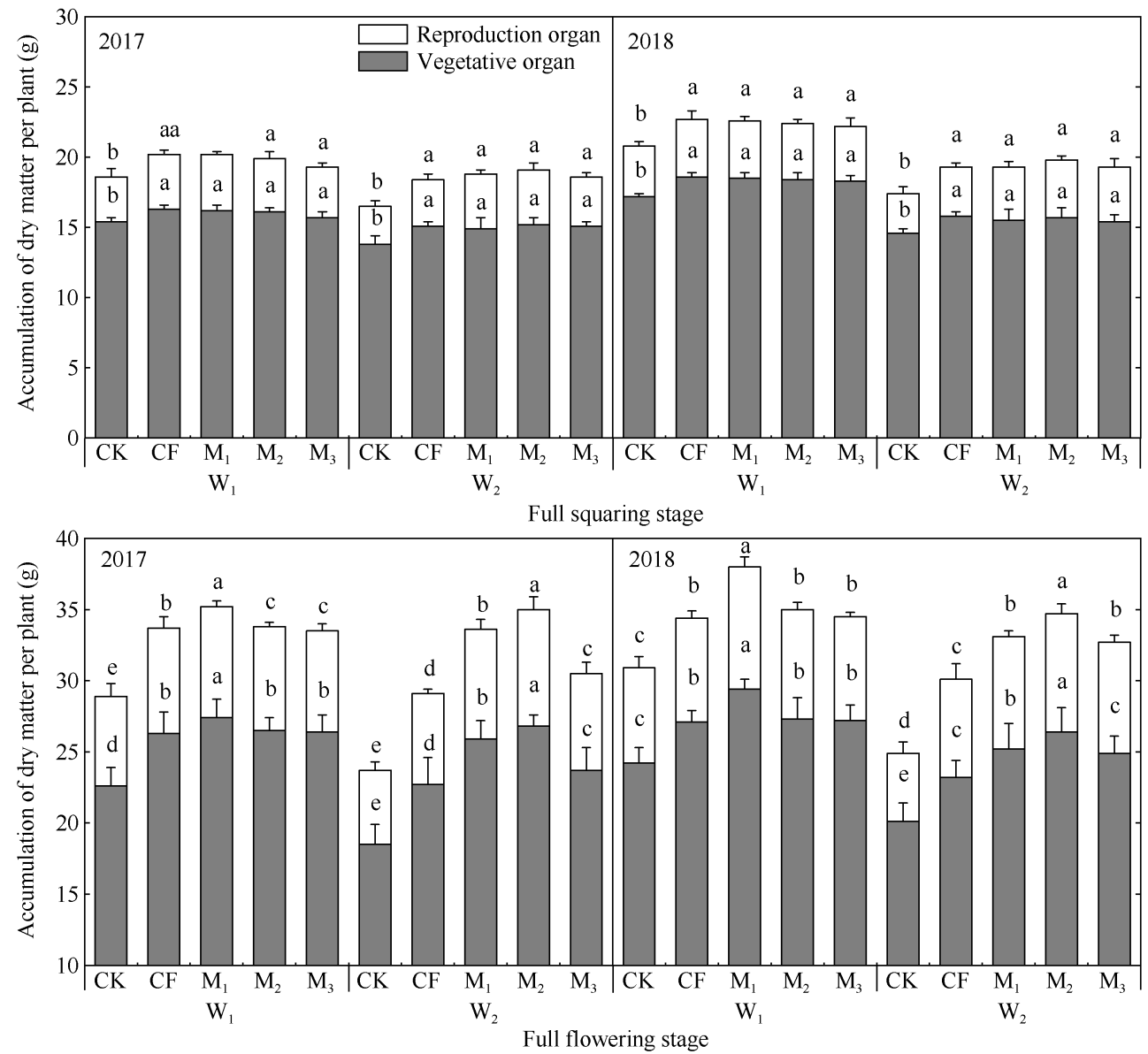

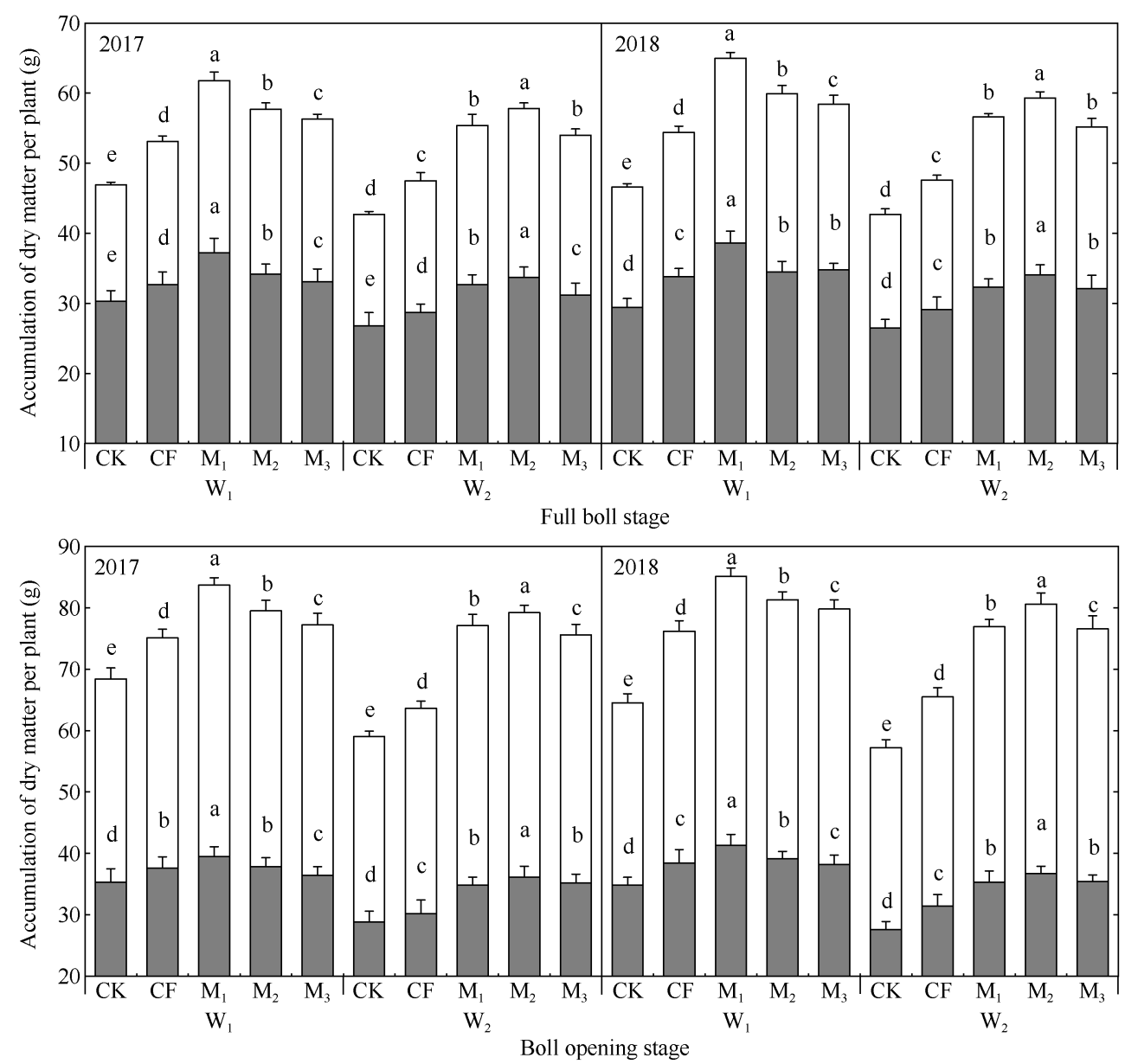

图 4 不同处理对棉花地上部干物质的影响

Fig. 4 Effects of different treatments on cotton plant dry biomass 不同字母表示同一年份不同处理差异显著 $(P<0.05)$ 。处理同图 2 。

Different letters in the same year mean significant difference among different treatments at $P<0.05$. Treatments are the same as those given in Fig. 2.

\section{4 不同灌溉量下有机无机肥配施对棉花产量 及构成因素的影响}

由表 2 可知, 亏缺灌溉 $\mathrm{W}_{2}$ 下棉花单株铃数、籽 棉产量较充分灌溉 $\mathrm{W}_{1} 2$ 年平均分别降低 $9.6 \%$ 和 $8.9 \%$, 而单铃重、衣分无显著差异。充分灌溉 $\mathrm{W}_{1}$ 下, 各施肥处理间单株铃数及籽棉产量表现为 $\mathrm{M}_{1}>\mathrm{M}_{2}>\mathrm{M}_{3}>\mathrm{CF}>\mathrm{CK}$, 其中 $\mathrm{M}_{1}$ 单株坽数和籽棉产量 较 $\mathrm{CF}$ 两年平均分别提高 $17.2 \%$ 和 $6.9 \%, \mathrm{M}_{2}$ 和 $\mathrm{M}_{3}$ 籽 棉产量无显著差异, 较 $\mathrm{CF}$ 平均增产分别为 $3.0 \%$ 和 $1.5 \%, \mathrm{M}_{1} 、 \mathrm{M}_{2} 、 \mathrm{M}_{3}$ 和 $\mathrm{CF}$ 处理间单铃重和衣分无显 著差异, 但各施肥处理单铃重均显著高于 $\mathrm{CK}$ $(P<0.05)$ 。亏缺灌溉 $\mathrm{W}_{2}$ 下, 各施肥处理单株皊数和 籽棉产量表现为 $\mathrm{M}_{2}>\mathrm{M}_{1}>\mathrm{M}_{3}>\mathrm{CF}>\mathrm{CK}, \mathrm{M}_{2} 、 \mathrm{M}_{1}$ 和 $\mathrm{M}_{3}$ 较 $\mathrm{CF}$ 单株铃数平均增加 $22.1 \% 、 13.1 \%$ 和 $10.1 \%$, 籽 棉产量平均提高 $19.9 \%$ 、15.7\%和 $13.2 \%$, 各施肥处 理间单铃重和衣分无显著差异。方差分析显示, 不
同灌溉量与施肥对籽棉产量有显著的交互作用, 相 同有机肥配施条件下，亏缺灌溉 $\mathrm{W}_{2}$ 较充分灌溉 $\mathrm{W}_{1}$ 籽棉增产率有所提高, $M_{1} 、 M_{2}$ 和 $M_{3}$ 籽棉增产率较充 分灌溉 $\mathrm{W}_{1}$ 下 $\mathrm{M}_{1} 、 \mathrm{M}_{2}$ 和 $\mathrm{M}_{3}$ 增产率分别提高了 $13.0 \%$ 、 $12.7 \%$ 和 $11.7 \%$ ，表明有机肥配施化肥能够缓解水分 亏缺对籽棉产量的影响, 产生一定的补偿效应。

2.5 不同灌溉量下有机无机肥配施对灌溉水生 产力及土壤含水量的影响

由图 5 可知, 亏缺灌溉 $\mathrm{W}_{2}$ 下棉花 IWP 显著高 于 $\mathrm{W}_{1}$ 处理, 较 $\mathrm{W}_{1}$ 平均提高了 $82.3 \%$ 。在 $\mathrm{W}_{1}$ 下, $\mathrm{M}_{1}$ 处理 IWP 最高, 较 CF 2 年平均提高 $11.1 \%, \mathrm{M}_{2} 、 \mathrm{M}_{3}$ 与 $\mathrm{CF}$ 无显著差异, 各施肥处理均 IWP 均显著高于 $\mathrm{CK}(P<0.05)$, 亏缺灌溉 $\mathrm{W}_{2}$ 下, $\mathrm{M}_{1} 、 \mathrm{M}_{2}$ 和 $\mathrm{M}_{3}$ 棉花 IWP 均显著高于 $\mathrm{CF}(P<0.05)$, 较 $\mathrm{CF} 2$ 年平均分别提 高 $20.0 \% 、 19.8 \%$ 和 $13.3 \%, \mathrm{M}_{1}$ 与 $\mathrm{M}_{2}$ 无显著差异。 亏缺灌溉 $\mathrm{W}_{2}$ 土壤含水量显著低于 $\mathrm{W}_{1}$, 在盛蕾期、 
表 2 不同灌溉量和施肥处理对棉花产量及构成因素的影响

Table 2 Effects of different irrigation and fertilizer treatments on cotton yield and its components

\begin{tabular}{|c|c|c|c|c|c|c|c|c|c|}
\hline \multirow{2}{*}{$\begin{array}{c}\text { 灌溉 } \\
\text { Irrigation }\end{array}$} & \multirow{2}{*}{$\begin{array}{c}\text { 施肥 } \\
\text { Fertilizer }\end{array}$} & \multicolumn{2}{|c|}{$\begin{array}{c}\text { 单株铃数 } \\
\text { Number of bolls }\end{array}$} & \multicolumn{2}{|c|}{$\begin{array}{c}\text { 单铃重 } \\
\text { Boll mass (g) }\end{array}$} & \multicolumn{2}{|c|}{$\begin{array}{c}\text { 衣分 } \\
\text { Lint percentage }(\%)\end{array}$} & \multicolumn{2}{|c|}{$\begin{array}{c}\text { 籽棉产量 } \\
\text { Lint yield }\left(\mathrm{kg} \mathrm{hm}^{-2}\right) \\
\end{array}$} \\
\hline & & 2017 & 2018 & 2017 & 2018 & 2017 & 2018 & 2017 & 2018 \\
\hline \multirow[t]{5}{*}{$\mathrm{W}_{1}$} & CK & $3.9 \mathrm{~d}$ & $4.5 \mathrm{e}$ & $5.6 \mathrm{~b}$ & $5.9 \mathrm{~b}$ & $41.2 \mathrm{a}$ & $41.4 \mathrm{a}$ & $2758.4 \mathrm{~d}$ & $2939.7 \mathrm{~d}$ \\
\hline & $\mathrm{CF}$ & $5.4 \mathrm{c}$ & $5.6 \mathrm{~d}$ & $6.2 \mathrm{a}$ & $6.3 \mathrm{a}$ & $41.6 \mathrm{a}$ & $41.6 \mathrm{a}$ & $4285.3 \mathrm{c}$ & $4357.2 \mathrm{c}$ \\
\hline & $\mathrm{M}_{1}$ & $6.2 \mathrm{a}$ & $6.7 \mathrm{a}$ & $6.3 \mathrm{a}$ & $6.5 \mathrm{a}$ & $41.5 \mathrm{a}$ & $41.9 \mathrm{a}$ & $4581.6 \mathrm{a}$ & $4662.5 \mathrm{a}$ \\
\hline & $\mathrm{M}_{2}$ & $6.1 \mathrm{a}$ & $6.2 \mathrm{~b}$ & $6.2 \mathrm{a}$ & $6.3 \mathrm{a}$ & $41.4 \mathrm{a}$ & $41.7 \mathrm{a}$ & $4417.3 \mathrm{~b}$ & $4485.6 \mathrm{~b}$ \\
\hline & $\mathrm{M}_{3}$ & $5.7 \mathrm{~b}$ & $5.9 \mathrm{c}$ & $6.2 \mathrm{a}$ & $6.2 \mathrm{a}$ & $41.5 \mathrm{a}$ & $41.5 \mathrm{a}$ & $4368.7 \mathrm{~b}$ & $4405.7 \mathrm{~b}$ \\
\hline \multirow[t]{5}{*}{$\mathrm{W}_{2}$} & CK & $3.5 \mathrm{e}$ & $3.7 \mathrm{~d}$ & $5.5 \mathrm{~b}$ & $5.6 \mathrm{~b}$ & $42.7 \mathrm{a}$ & $42.6 \mathrm{a}$ & $2404.6 \mathrm{e}$ & $2513.5 \mathrm{e}$ \\
\hline & $\mathrm{CF}$ & $4.8 \mathrm{~d}$ & $5.1 \mathrm{c}$ & $5.9 \mathrm{a}$ & $6.0 \mathrm{a}$ & $42.6 \mathrm{a}$ & $42.8 \mathrm{a}$ & $3625.3 \mathrm{~d}$ & $3718.7 \mathrm{~d}$ \\
\hline & $\mathrm{M}_{1}$ & $5.5 \mathrm{~b}$ & $5.7 \mathrm{~b}$ & $6.1 \mathrm{a}$ & $6.1 \mathrm{a}$ & $42.5 \mathrm{a}$ & $42.5 \mathrm{a}$ & $4224.6 \mathrm{~b}$ & $4273.8 \mathrm{~b}$ \\
\hline & $\mathrm{M}_{2}$ & $5.8 \mathrm{a}$ & $6.3 \mathrm{a}$ & $6.2 \mathrm{a}$ & $6.3 \mathrm{a}$ & $42.3 \mathrm{a}$ & $42.6 \mathrm{a}$ & $4396.8 \mathrm{a}$ & $4415.1 \mathrm{a}$ \\
\hline & $\mathrm{M}_{3}$ & $5.3 \mathrm{c}$ & $5.6 \mathrm{~b}$ & $6.1 \mathrm{a}$ & $6.0 \mathrm{a}$ & $42.5 \mathrm{a}$ & $42.4 \mathrm{a}$ & $4128.3 \mathrm{c}$ & $4187.4 \mathrm{c}$ \\
\hline \multicolumn{2}{|c|}{ 灌水 Irrigation (W) } & $* *$ & $* *$ & ns & ns & ** & $* *$ & $* *$ & $* *$ \\
\hline \multicolumn{2}{|c|}{ 施肥 Fertilizer (F) } & $* *$ & $* *$ & $* *$ & $* *$ & $\mathrm{~ns}$ & $\mathrm{~ns}$ & $* *$ & $* *$ \\
\hline \multicolumn{2}{|c|}{ 灌水 $\times$ 施肥 $\mathrm{W} \times \mathrm{F}$} & $* *$ & $* *$ & ns & $*$ & ns & ns & $* *$ & $* *$ \\
\hline
\end{tabular}

同列不同小写字母表示各处理间在 0.05 水平差异显著。*表示差异显著 $(P<0.05), * *$ 表示差异极显著 $(P<0.01), \mathrm{ns}$ 表示差异不显著 $(P>$ 0.05 )。处理同图 2。

Different lowercase letters in the same year mean significant difference among different treatments at the 0.05 level. * indicates significance $(P<0.05),{ }^{* *}$ indicates highly significance $(P<0.01)$, ns indicates no significance $(P>0.05)$. Treatments are the same as those given in Fig. 2.

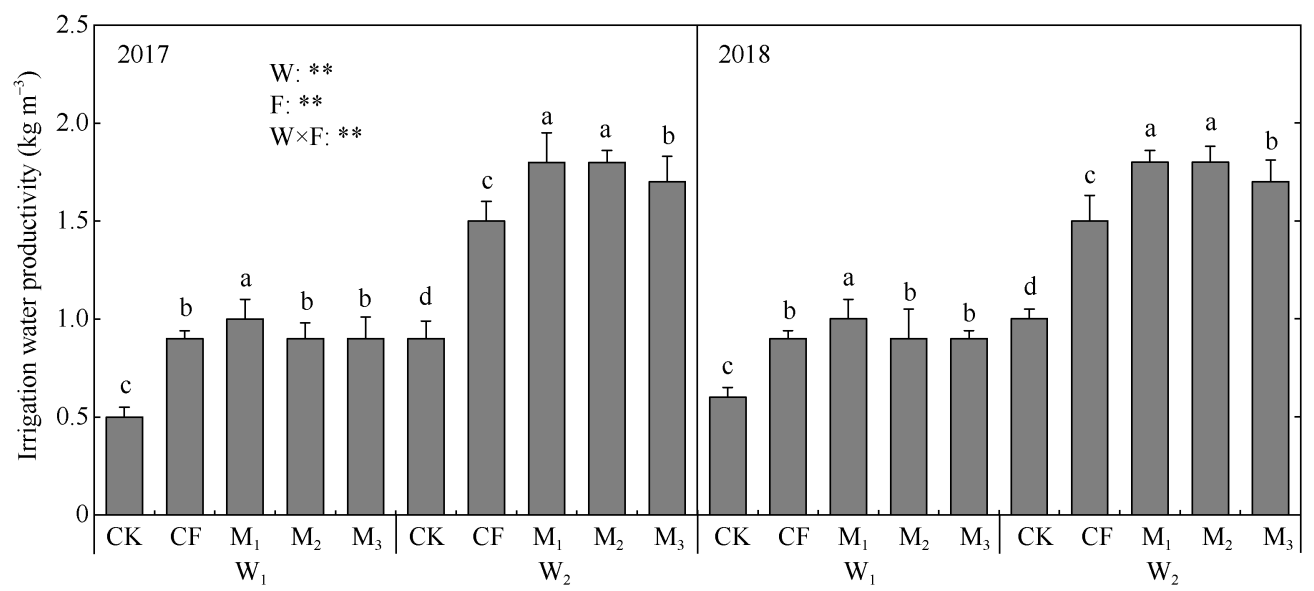

图 5 不同处理对棉花灌溉水生产力的影响

Fig. 5 Effect of different treatments on irrigation water productivity of cotton

不同字母表示同一年份不同处理差异显著 $(P<0.05)$ 。 $\mathrm{W}$ 表示灌水; $\mathrm{F}$ 表示施肥; $\mathrm{W} \times \mathrm{F}$ 表示灌水与施肥的交互作用。处理同图 2 。

Different letters in the same year mean significant difference among different treatments at $P<0.05$. M: irrigation; F: fertilizer; W $\times \mathrm{F}$ : interaction effects between irrigation and fertilizer. Treatments are the same as those given in Fig. 2 .

盛花期、盛铃期和吐絮期平均分别降低 $83.5 \%$ 、 $83.6 \% 、 95.1 \%$ 和 $88.2 \%, \mathrm{~W}_{1}$ 下，各施肥处理在盛蕾期 和盛花期土壤含水量无显著差异，盛铃期和吐絮期 各有机肥配施处理均显著高于 $\mathrm{CF}$ 和 $\mathrm{CK}, \mathrm{M}_{1} 、 \mathrm{M}_{2}$ 和 $\mathrm{M}_{3}$ 处理间无显著差异; 亏缺灌溉 $\mathrm{W}_{2}$ 下，各施肥处
理在盛蕾期和盛花期无显著差异, 在盛铃期和吐絮 期有机肥配施处理均显著高于 $\mathrm{CF}$ 和 $\mathrm{CK}$, 表现为 $\mathrm{M}_{3}>\mathrm{M}_{2}>\mathrm{M}_{1}>\mathrm{CK}>\mathrm{CF}, \mathrm{M}_{2}$ 和 $\mathrm{M}_{3}$ 无显著差异, 在盛铃期 $\mathrm{M}_{2} 、 \mathrm{M}_{3}$ 较 $\mathrm{CF}$ 土壤含水量分别提高 $53.7 \%$ 和 $55.5 \%$ ，表 明化肥减量配施有机肥能够增加土壤耕层保水性。 


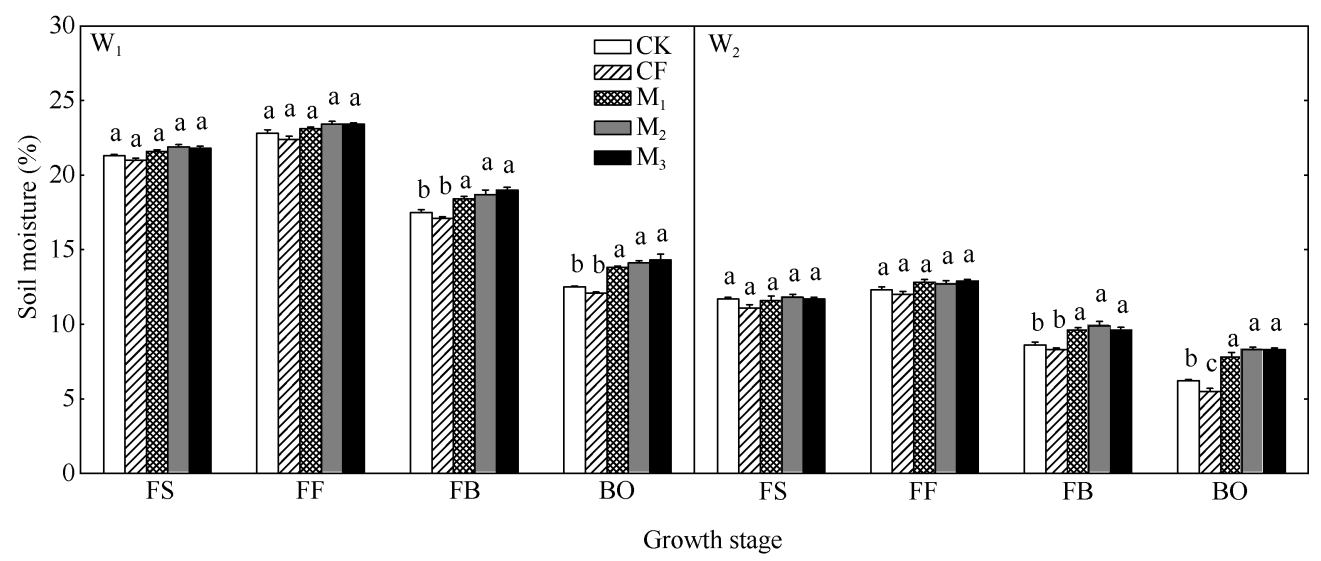

图 6 不同灌溉量和施肥处理对土壤含水量的影响

Fig. 6 Effect of different irrigation and fertilizer treatments on soil moisture

不同字母表示同一年份不同处理差异显著 $(P<0.05)$ 。 FS: 盛蕾期; FF：盛花期; EFB：盛铃前期; FB：盛铃期; BO:吐絮期。处理同图 2。 Different letters in the same year mean significant difference among different treatments at $P<0.05$. FS: full squaring stage; FF: full flowering stage; EFB: early stage of full boll; FB: full boll stage; BO: boll opening stage. Treatments are the same as those given in Fig. 2.

\section{3 讨论}

植物叶片是光合作用的主要载体, 叶面积指数 (LAI)能够反映植物截获光的能力, 是冠层结构性能 的重要指标 ${ }^{[2]}$ 。前人研究表明, 有机肥与化肥配施能 显著增加作物群体 LAI, 并能延缓功能叶片衰老期, 有利于维持较高的光合速率, 加快植株干物质的积 累 ${ }^{[19,21-22]}$ 。本研究中亏缺灌溉下棉花 LAI 在各生育 期显著降低并促使 LAI 峰值提前, 使光合有效面积 减小, 进而影响光合物质生产和积累。化肥减量配 施有机肥较单施化肥能够显著提高棉花盛蕾期以后 棉花 LAI, 使生育后期 LAI 下降缓慢, 光合面积充 足, 保证了较高的光截获率, 有利于维持较高的光 合物质生产力。本研究表明, 化肥减量配施有机肥 较单施化肥显著提高了各生育期棉花净光合速率、 气孔导度, 降低了胞间 $\mathrm{CO}_{2}$ 浓度, 与徐瑞强等 ${ }^{[19]}$ 、 徐海东等 ${ }^{[21]}$ 的结果一致, 其原因可能是化肥配施有 机肥可以调控土壤氮素的固持和释放, 协调土壤氮 素供应, 使肥效相互促进, 一方面促进了有机肥的 腐熟, 增加了土壤有机质含量, 提高了土壤肥力; 另一方面减少了无机氮与土壤的接触, 降低了氮肥 被土壤的固定作用, 提高了土壤养分利用率 ${ }^{[13,23]}$ 。本 研究中, 充分灌溉量下各有机肥配施光合速率表现 为 $M_{1}>M_{2}>M_{3}$, 而在亏缺灌溉下表现为 $M_{2}>M_{1}>M_{3}$, 其原因可能是低比例有机肥配施量处理中无机氮含 量高, 充足的水分有助于氮肥肥效的发挥, 而在水 分亏缺下, 过量施氮或施氮不足均不利于提高棉花 叶片光合性能 ${ }^{[24]}$ 。光合作用的强弱受叶肉细胞光合 能力和气孔导度的双重影响, 胞间 $\mathrm{CO}_{2}$ 浓度和气孔
导度的变化方向是决定叶片净光合速率变化的主要 原因 ${ }^{[25]}$, 本研究中净光合速率和气孔导度与胞间 $\mathrm{CO}_{2}$ 浓度的变化趋势相反, 说明施肥处理棉花光合 性能的改变是由非孔因素导致, 非气孔因素阻碍了 $\mathrm{CO}_{2}$ 的利用, 造成 $\mathrm{CO}_{2}$ 的积累。

干物质积累与分配是作物产量形成的物质基 础 ${ }^{[26]}$, 合理施肥能够促进干物质的积累与合理分配, 从而提高产量 ${ }^{[27]}$ 。郑凤霞等 ${ }^{[28]}$ 研究指出, 有机无机 肥配施提高了冬小麦干物质积累能力并增加了光合 产物向籽粒的分配; 刘彦伶等 ${ }^{[26]}$ 研究表明, 有机无 机肥配施有利于促进水稻干物质的积累及其向籽粒 的转运, 从而提高了产量; 崔红艳等 ${ }^{[27]}$ 研究显示, 有机无机肥配施促进了胡麻对养分的摄取和水分的 吸收, 有利于胡麻花前干物质的积累和花后干物质 向籽粒分配。本研究与前人研究结果一致, 水分亏 缺显著降低棉花地上部干物质的积累, 盛蕾期后, 水分亏缺下化肥减量配施有机肥能显著提高棉花营 养器官和生殖器官干物质积累量, 并促进光合产物 向生殖器官的分配, 其中 $\mathrm{M}_{2}$ 提高效果最显著, 可能 是适宜的化肥减量配施有机肥后, 使植株的蛋白质 含量增加, 并增加了单株有机物质积累量, 使得作 物生长过程吸收的养分更多地向生殖器官转移 ${ }^{[19]}$ 。

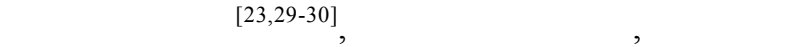
有机肥能够显著提高作物的产量, 本研究结果显示, 水分亏缺下棉花单株铃数、籽棉产量较正常水分显 著降低, 化肥减量配施有机肥能显著提高棉花单株 铃数、单铃重和籽棉产量, 一方面, 化肥配施有机肥 能够改善土壤理化性质, 协调土壤速效与缓效养分 
供给 ${ }^{[26]}$; 另一方面, 有机无机肥配施既保证了一定 数量的有效铃数, 又防止棉花生长后期早衰, 延长 花铃期光合作用时间，保证棉花生长发育后期干物 质的积累, 从而提高单铃重和籽棉产量。

水资源短缺是影响干旱地区农田生态系统作物 生产力提高的主要因子 ${ }^{[7]}$ ，促进作物对有限水资源 的充分利用、减轻水分亏缺对作物光合生产的影响 是干旱灌溉农业区生产中需要解决的主要问题，在 一定条件下，施肥能够提高作物的水分利用效率, 增加作物的抗旱能力，具有“以肥调水”的作用 ${ }^{[31]}$ 。

已有研究表明, 施用有机肥能够显著提高土壤䛎水 量, 提高作物水分利用率 ${ }^{[11]}$, 并有利于减少土壤表 面水分蒸发 ${ }^{[32]}$, 在一定程度上能够缓解干旱胁迫影 响 ${ }^{[7]}$ 。本研究中, 水分亏缺下化肥减量配施有机肥较 单施化肥能显著提高灌溉水生产力和棉花生育后期 土壤耕层含水量, 促进对有限灌溉水资源的充分利 用, 其主要原因可能是有机肥为土壤微生物提供了 丰富的碳源, 提高了微生物活性, 通过对土壤团聚 体的形成与稳定性的促进作用，改善了土壤结构 ${ }^{[32]}$, 增加了土壤的保水保肥性 ${ }^{[13,30]}$, 从而能够缓解水分 亏缺对棉花光合生产的影响，其中 $\mathrm{M}_{2}$ 处理 $(50 \%$ 化 肥 $+50 \%$ 有机肥)在水分亏缺下表现最佳, 既实现了 化肥减量, 又缓解了水分亏缺对作物的影响。但由 于同一施肥处理经过多年保持后更能反映出实际效 果 ${ }^{[11]}$, 在水分亏缺下化肥减量配施有机肥对棉花生 长发育的调控, 还有待长期深入的研究。

\section{4 结论}

亏缺灌溉下棉花叶面积指数在各生育期降低并 促使峰值提前, 使光合有效面积减小, 影响光合物 质生产和干物质积累, 籽棉产量显著降低。化肥减 量配施有机肥能有效提高盛蕾期后棉花叶面积指数, 提高植株光合性能, 促进地上部干物质的积累并向 生殖器官转运, 有利于后期籽棉产量的形成, 同时 能够提高土壤耕层保水性以及促进对有限灌溉水资 源的充分利用，从而缓解水分亏缺对棉花光合物质 生产的影响。在不同的灌溉水分条件下有机肥最佳 配施比例不同，其中在充分灌溉下， $\mathrm{M}_{1}$ 处理 $(75 \%$ 化 肥 $+25 \%$ 有机肥)光合物质生产力最高, 籽棉产量平 均较单施化肥和不施肥分别提高了 $6.9 \%$ 和 $62.1 \%$, 而在亏缺灌溉下， $\mathrm{M}_{2}$ 处理( $50 \%$ 化肥 $+50 \%$ 有机肥)表 现最佳, 籽棉产量平均较 $\mathrm{CF}$ 和 $\mathrm{CK}$ 分别提高了 $19.9 \%$ 和 79.3\%。通过适宜比例的化肥减量配施有机
肥可以实现化肥减量，同时又能缓解水分亏缺对作 物光合生产的影响, 这对于水资源紧缺且因化肥过 量施用出现环境问题的干旱灌溉农业区具有重要意 义。

\section{References}

[1] 罗宏海, 张宏芝, 陶先萍, 张亚黎, 张旺锋. 水氮运筹对膜下 滴灌棉花光合特性及产量形成的影响. 应用生态学报, 2013, 24: 407-415.

Luo H H, Zhang H Z, Tao X P, Zhang Y L, Zhang W F. Effects of water and nitrogen management modes on the leaf photosynthetic characters and yield formation of cotton with under-mulch drip irrigation. Chin J Appl Ecol, 2013, 24: 407-415 (in Chinese with English abstract).

[2] 王虎兵, 曹红霞, 郝舒雪, 潘小燕. 温室番茄植株养分和光合 对水肥耦合的响应及其与产量关系. 中国农业科学, 2019, 52: 1761-1771.

Wang H B, Cao H X, Hao S X, Pan X Y. Responses of plant nutrient and photosynthesis in greenhouse tomato to water-fertilizer coupling and their relationship with yield. Sci Agric Sin, 2019, 52: 1761-1771 (in Chinese with English abstract).

[3] 李阳阳, 费聪, 崔静, 王开勇, 马富裕, 樊华. 滴灌甜菜对块 根膨大期水分亏缺的补偿性响应. 作物学报, 2016, 42: $1727-1732$.

Li Y Y, Fei C, Cui J, Wang K Y, Ma F Y, Fan H. Compensation response of drip-irrigated sugar beets (Beta vulgaris L.) to different water deficits during storage root development. Acta Agron Sin, 2016, 42: 1727-1732 (in Chinese with English abstract).

[4] 王凯丽, 高彦创, 李姗, 张梦璐, 吴智豪, 刘连涛, 孙红春, 李 存东, 张永江. 短期干旱胁迫下棉花气孔表现及光合特征研 究. 中国生态农业学报, 2019, 27: 901-907.

Wang K L, Gao Y Z, Li S, Zhang M L, Wu Z H, Liu T T, Sun H T, Li C D, Zhang Y J. Response of leaf stomata and photosynthetic parameters to short-term drought stress in cotton (Gossypium hirsutum L.). Chin J Eco-Agric, 2019, 27: 901-907 (in Chinese with English abstract).

[5] 罗宏海, 张亚黎, 张旺锋, 白慧东, 何在菊, 杜明伟, 张宏芝. 新疆滴灌棉花花铃期干旱复水对叶片光合特性及产量的影响. 作物学报, 2008, 34: 171-174.

Luo H H, Zhang Y L, Zhang W F, Bai H D, He Z J, Du M W, Zhang $\mathrm{H} \mathrm{Z}$. Effects of rewatering after drought stress on Photosynthesis and yield during flowering and boll-setting stage of cotton under-mulch-drip irrigation in Xinjiang. Acta Agron Sin, 2008, 34: 171-174 (in Chinese with English abstract).

[6] 张珍贤, 王华, 蔡传涛, 刘贵周. 施肥对干旱胁迫下幼龄期小 粒咖啡光合特性及生长的影响. 中国生态农业学报, 2015, 23: 832-840.

Zhang Z X, Wang H, Cai C T, Liu G Z. Effects of fertilization on photosynthetic characteristics and growth of Coffea arabica L. at juvenile stage under drought stress. Chin $J$ Eco-Agric, 2015, 23: 832-840 (in Chinese with English 
abstract).

[7] 张永清, 苗果园. 水分胁迫条件下有机肥对小麦根苗生长的 影响. 作物学报, 2006, 32: 811-816.

Zhang Y Q, Miao G Y. Effects of manure on root and shoot growth of winter wheat under water stress. Acta Agron Sin, 2006, 32: 811-816 (in Chinese with English abstract).

[8] 石洪亮, 张巨松, 严青青, 李春艳, 李健伟. 氮肥对非充分灌 溉下棉花产量及品质的补偿作用. 植物营养与肥料学报, 2018, 24: 134-145.

Shi H L, Zhang J S, Yan Q Q, Li C Y, Li J W. Compensation effects of nitrogen fertilizer on yield and quality of cotton under insufficient irrigation. Plant Nutr Fert Sci, 2018, 24: 134-145 (in Chinese with English abstract).

[9] 杨荣, 苏永中. 水氮供应对棉花花铃期净光合速率及产量的 调控效应. 植物营养与肥料学报, 2011, 17: 404-410.

Yang R, Su Y Z, Responses of net photosynthetic rate in flowering and boll-forming stages, and cotton yield to irrigation and nitrogen fertilizer application. Plant Nutr Fert Sci, 2011, 17: 404-410 (in Chinese with English abstract).

[10] 王兴龙, 朱敏, 杨帆, 豆攀, 张嘉莉, 马晓君, 袁继超, 孔凡磊. 配施有机肥减氮对川中丘区土壤微生物量与酶活性的影响. 水土保持学报, 2017, 31(3): 271-276.

Wang X L, Zhu M, Yang F, Dou P, Zhang J L, Ma X J, Yuan J C, Kong F L. Effects of reducing nitrogen and applying organic fertilizers on soil microbial biomass carbon and enzyme activity in the hilly area of central Sichuan basin. $J$ Soil Water Conserv, 2017, 31(3): 271-276 (in Chinese with English abstract).

[11] 路文涛, 贾志宽, 张鹏, 蔡太义, 李儒, 侯贤清, 杨保平, 李永 平. 宁南旱区有机培肥对冬小麦光合特性和水分利用效率的 影响. 植物营养与肥料学报, 2011, 17: 1066-1074.

Lu W T, Jia Z K, Zhang P, Cai T Y, Li R, Hou X Q, Yang B P, Li Y P. Effects of organic fertilization on winter wheat photosynthetic characteristics and water use efficiency in semi-arid areas of southern Ningxia. Plant Nutr Fert Sci, 2011, 17: 1066-1074 (in Chinese with English abstract).

[12] 董春华, 高菊生, 曾希柏, 刘强, 徐明岗, 文石林. 长期有机 无机肥配施下红壤性稻田水稻产量及土壤有机碳变化特征. 植物营养与肥料学报, 2014, 20: 336-345.

Dong C H, Gao J S, Zeng X B, Liu Q, Xu M G, Wen S L. Effects of long-term organic manure and inorganic fertilizer combined application on rice yield and soil organic carbon content in reddish paddy fields. Plant Nutr Fert Sci, 2014, 20: 336-345 (in Chinese with English abstract).

[13] 刘红江, 陈虞雯, 孙国峰, 陈留根, 郑建初. 有机肥-无机肥不 同配施比例对水稻产量和农田养分流失的影响. 生态学杂志, 2017, 36: 405-412.

Liu H J, Chen Y W, Sun G F, Chen L G, Zheng J C. Effects of different organic-inorganic fertilizer combination ratios on rice yield and nutrient loss with surface runoff. Chin J Ecol, 2017, 36: 405-412 (in Chinese with English abstract).

[14] 侯俊, 王帅, 崔士通, 王会刚, 张卫峰. 沙土地有机肥替代化 肥与灌溉优化在苜宿上的耦合效应研究. 中国土壤与肥料, 2018, (6): 104-111.

Hou J, Wang S, Cui S T, Wang H G, Zhang W F. The coupling effect on alfalfa from integrated improvement of replacing chemical with organic fertilization and optimized irrigation on sandy soil. China Soils Fert, 2018, (6): 104-111 (in Chinese with English abstract).

[15] 宋福, 庄生仁, 赵贵宾, 李虹. 加强高产集成技术应用, 推动 甘肃棉花产业提质增效. 中国棉花, 2012, 39(7): 7-9.

Song F, Zhuang S R, Zhao G B, Li H. Strengthen the high yield integrated technology application, promote quality and benefits in Gansu cotton industry. China Cotton, 2012, 39(7): 7-9 (in Chinese).

[16] 冯克云, 王宁, 南宏宇. 甘肃河西棉花全生育期不同灌溉量对 生长发育的影响及抗旱性评价. 干旱地区农业研究, 2015, 33(5): 140-146.

Feng K Y, Wang N, Nan H Y. Effects of different irrigation volumes during the entire growth period on development of cotton in Hexi area of Gansu and evaluation of its drought resistance. Agric Res Arid Areas, 2015, 33(5): 140-146 (in Chinese with English abstract).

[17] 冯克云, 张秉贤, 南宏宇. 河西内陆灌区不同灌水施氮水平对 棉花产量构成的影响. 干旱地区农业研究, 2011, 29(6): 49-53. Feng K Y, Zhang B X, Nan H Y. Effect of different water and nitrogen supply on yield and its components of cotton in inland irrigation district of Hexi in Gansu. Agric Res Arid Areas, 2011, 29(6): 49-53 (in Chinese with English abstract).

[18] 石洪亮, 严青青, 张巨松, 李春艳, 窦海涛. 氮肥对非充分灌 溉下棉花花铃期光合特性及产量的补偿作用. 作物学报, 2018, 44: 1196-1204.

Shi H L, Yan Q Q, Zhang J S, Li C Y, Dou H T. Compensation effect of nitrogen fertilizer on photosynthetic characteristics and yield during cotton flowering boll-setting stage under non-sufficient drip irrigation. Acta Agron Sin, 2018, 44: 1196-1204 (in Chinese with English abstract).

[19] 徐瑞强, 徐海东, 董合林, 苏丽丽, 唐江华, 徐文修, 范小利. 液态有机肥与氮肥配施对棉花生理特性及产量的影响. 中国 农学通报, 2019, 35(13): 42-47.

Xu R Q, Xu H D, Dong H L, Su L L, Tang J H, Xu W X, Fan $X$ L. Liquid organic fertilizer and nitrogen fertilizer management: effects on physiological characteristics and yield of cotton. Chin Agric Sci Bull, 2019, 35(13): 42-47 (in Chinese with English abstract).

[20] 王谦, 陈景玲, 孙治强. LAI-2000 冠层分析仪在不同植物群体 光分布特征研究中的应用. 中国农业科学, 2006, 39: 922-927.

Wang Q, Chen J L, Sun Z Q. The utility of LAI-2000 canopy analyzer studying the sunlight distribution characteristics in different plant colonies. Sci Agric Sin, 2006, 39: 922-927 (in Chinese with English abstract).

[21] 徐海东, 董合林, 苏丽丽, 徐文修, 唐江华, 陈传信, 张永杰, 胡丽娟. 液态有机肥对滴灌棉花光合特性及产量形成规律的 影响. 中国农学通报, 2017, 33(20): 71-77.

Xu H D, Dong H L, Su L L, Xu W X, Tang J H, Chen C X, Zhang Y J, Hu L J. Effect of liquid organic fertilizer on photosynthetic characteristics and yield formation of cotton under drip irrigation. Chin Agric Sci Bull, 2017, 33(20): 71-77 (in Chinese with English abstract).

[22] 赵隽, 董树亭, 刘鹏, 张吉旺, 赵斌. 有机无机肥长期定位配 施对冬小麦群体光合特性及籽粒产量的影响. 应用生态学报, 2015, 26: 2362-2370. 
Zhao J, Dong S T, Liu P, Zhang J W, Zhao B. Effects of long-term mixed application of organic and inorganic fertilizers on canopy apparent photosynthesis and yield of winter wheat. Chin J Appl Ecol, 2015, 26: 2362-2370 (in Chinese with English abstract).

[23] 王艳丽, 吴鹏年, 李培富, 王西娜, 朱旭. 有机肥配施氮肥对 滴灌春玉米产量及土壤肥力状况的影响. 作物学报, 2019, 45: 1230-1237.

Wang Y L, Wu P N, Li P F, Wang X N, Zhu X. Effects of organic manure combined with nitrogen fertilizer on spring maize yield and soil fertility under drip irrigation. Acta Agron Sin, 2019, 45: 1230-1237 (in Chinese with English abstract).

[24] 刘瑞显, 王友华, 陈兵磷, 郭文琦, 周治国. 花铃期干旱胁迫 下氮素水平对棉花光合作用与叶绿素荧光特性的影响. 作物 学报, 2008, 34: 675-683.

Liu R X, Wang Y H, Chen B L, Guo W Q, Zhou Z G. Effects of nitrogen levels on photosynthesis and chlorophyll fluorescence characteristics under drought stress in cotton flowering and boll-forming stage. Acta Agron Sin, 2008, 34: 675-683 (in Chinese with English abstract).

[25] 宫香伟, 党科, 李境, 罗艳, 赵冠, 杨璞, 高小丽, 高金锋, 王 鹏科, 冯佰利. 糜子绿豆间作模式下糜子光合物质生产及水 分利用效率. 中国农业科学, 2019, 52: 4139-4153.

Gong X W, Dang K, Li J, Luo Y, Zhao G, Yang P, Gao X L, Gao J F, Wang P K, Feng B L. Effects of different intercropping patterns on photosynthesis production characteristics and water use efficiency of Proso millet. Sci Agric Sin, 2019, 52: 4139-4153 (in Chinese with English abstract).

[26] 刘彦伶, 李渝, 白怡婧, 黄兴成, 张雅蓉, 张萌, 张文安, 蒋太 明. 长期不同施肥对水稻干物质和磷素积累与转运的影响. 植物营养与肥料学报, 2019, 25: 1146-1156.

Liu Y L, Li Y, Bai Y J, Huang X C, Zhang Y R, Zhang M, Zhang W A, Jiang T M. Effect of long-term fertilization patterns on dry matter and phosphorus accumulation and translocation in rice. Plant Nutr Fert Sci, 2019, 25: 1146-1156 (in Chinese with English abstract).

[27] 崔红艳, 胡发龙, 方子森, 牛俊义. 有机无机肥配施对胡麻的 耗水特性和干物质积累与分配的影响. 水土保持学报, 2015, 29: 282-288.

Cui H Y, Hu F L, Fang Z S, Niu J Y. Effects of combined application of chemical fertilizers and manure on water consumption characteristics and dry matter accumulation and allocation of oil flax. J Soil Water Conserv, 2015, 29: 282-288 (in Chinese with English abstract).

[28] 郑凤霞, 董树亭, 刘鹏, 张吉旺, 赵斌. 长期有机无机肥配施 对冬小麦籽粒产量及氨挥发损失的影响. 植物营养与肥料学 报, 2017, 23: 567-577.

Zheng F X, Dong S T, Liu P, Zhang J W, Zhao B. Effects of combined application of manure and chemical fertilizers on ammonia volatilization loss and yield of winter wheat. Plant Nutr Fert Sci, 2017, 23: 567-577 (in Chinese with English abstract).

[29] 王晓娟, 贾志宽, 梁连友, 丁瑞霞, 王敏, 李涵. 不同有机肥 量对旱地玉米光合特性和产量的影响. 应用生态学报, 2012, 23: 419-425.

Wang X J, Jia Z K, Liang L Y, Ding R X, Wang M, Li H. Effects of organic fertilizer application rate on leaf photosynthetic characteristics and grain yield of dryland maize. Chin J Appl Ecol, 2012, 23: 419-425 (in Chinese with English abstract).

[30] 王宁, 南宏宇, 冯克云. 化肥减量配施有机肥对棉田土壤微生 物生物量、酶活性和棉花产量的影响. 应用生态学报, 2020, 31: 173-181.

Wang N, Nan H Y, Feng K Y. Effects of reduced chemical fertilizer with organic fertilizer application on soil microbial biomass, enzyme activity and cotton yield. Chin J Appl Ecol, 2020, 31: 173-181 (in Chinese with English abstract).

[31] 翟丙年, 李生秀. 不同水分状况下施氮对夏玉米水分利用效 率的影响. 植物营养与肥料学报, 2005, 11: 473-480.

Zhai B N, Li S X. Effects of nitrogen nutrition on summer maize water use efficiency under different status of soil moisture. Plant Nutr Fert Sci, 2005, 11: 473-480 (in Chinese with English abstract)

[32] 张宏媛, 卢闯, 逢焕成, 张建丽, 刘娜, 张晓丽, 李玉义. 亚表 层培肥结合覆膜提高干旱区盐碱地土壤肥力及优势菌群丰度 的机理. 植物营养与肥料学报, 2019, 25: 1461-1472.

Zhang H Y, Lu C, Pang H C, Zhang J L, Liu N, Zhang X L, Li Y Y. Mechanism of subsurface organic amendment combined with plastic mulching increasing soil fertility and microflora in an arid saline soil. Plant Nutr Fert Sci, 2019, 25: 1461-1472 (in Chinese with English abstract). 